Журнал«Герстективита інновації наукиљ

(Серія «Гедагогіка», Серія«Гтихологія», Серія«Медицина»

№(6) 2022

УДК 354:328.185

https://doi.org/10.52058/2786-4952-2022-1(6)-294-306

Одінцова Ольга Олександрівна старший викладач, Донецький національний університет ім. В. Стуса, вул. 600-річчя, 21, м. Вінниця, 21021, тел.: (032) 50-87-79, https://orcid.org/0000-0001-5644-3394

Хало Зоряна Петрівна кандидат педагогічних наук, доцент, доцент кафедри мовної та міжкультурної комунікації, Дрогобицький державний педагогічний університет, вул. І. Франка, 24, м. Дрогобич, 82100, тел.: (0324) 41-04-74, https://orcid.org/0000-0002-0545-6547

Балтремус Володимир Свгенійович кандидат педагогічних наук, викладач кафедри українознавства, Вінницький національний медичний університет, вул. Пирогова, 56, м. Вінниця, 21018, тел.: (0432) 57-03-60, https://orcid.org/0000-0003-4370-1328

\title{
ДИСТАНЦЙНЕ НАВЧАННЯ ЯК ВИКЛИК СУЧАСНОЇ УНІВЕРСИТЕТСЬКОЇ ОСВІТИ: ПРОБЛЕМИ І ПЕРСПЕКТИВИ
}

Анотація. У статті розглянуто концепцію дистанційного навчання 3 точки зору різних науковців, окреслено вимоги до системи вищої освіти, які висуває сучасне інформаційне суспільство, досліджено особливості застосування методів дистанційного навчання у закладах вищої освіти. Проаналізовано сучасні тенденції в освіті, що виникли внаслідок активного використання дистанційних методів у навчальному процесі. Дано оцінку найважливішим факторам, що впливають на якість дистанційного навчання у вищій школі. Сформульовано сучасні вимоги до якості освітнього процесу, зокрема, зазначено, що технології дистанційного навчання спрямовані на подолання розриву між соціально-економічним становищем різних груп населення та країн 3 різним економічним розвитком. Встановлено перелік умов використання різних технологій дистанційного навчання, надано оцінку змін у сучасній освіті, зокрема підкреслено необхідність чіткого усвідомлення особливостей дистанційного навчання порівняно з традиційним. Розкрито питання про унікальну доцільність використання дистанційного навчання в сучасних умовах. У центрі уваги статті - особливості освітніх тенденцій, які ускладнюють розвиток дистанційного навчання, а також напрями реформування сучасного дистанційного навчального процесу 3 точки зору впровадження нових підходів до дистанційного навчання. Розглянуто систему викликів в освітній галузі, що пов'язані 3 дистанційним навчальним процесом. Зокрема, зазначається, що після вивчення дисципліни студент ЗВО повинен чітко усвідомлювати, які навички та компетенції він набув. 
Наголошено, що ефективна дистанційна взаємодія є одним із інструментів, за допомогою якого можна відстежити всі слабкі та сильні сторони навчального процесу, виявити прогалини в ньому. Виокремлено найважливіші напрямки подальшого розвитку дистанційної університетської освіти, зокрема іiі управлінсько-організаційне, матеріально-технічне і фінансове забезпечення дистанційного навчання, кадрове забезпечення потреб дистанційної освіти, методичне забезпечення 3 урахуванням специфіки дистанційного навчання, просування дистанційної освіти на освітньому ринку і ринку праці, створення на базі інфраструктур ЗВО проєкту мережі підтримки студентів дистанційної форми навчання в різних регіонах України.

Ключові слова: дистанційне навчання, форма навчання, освітні програми, вища освіта, інформаційні технології електронного навчання.

Odintsova Olga Oleksandrivna Senior Lecturer, Vasyl' Stus Donetsk National University, 600th St., 21, Vinnytsia, 21021, tel: (032) 50-87-79, https://orcid.org/0000-0001-5644-3394

Khalo Zoriana Petrivna PhD of Pedagogical Sciences, Associate Professor of the Department of Linguistic and Intercultural Communication, Drohobych State Pedagogical University, I. Franko St., 24, Drohobych, 82100, tel.: (03-24) 41-04-74, https://orcid.org/0000-0002-0545-6547

Baltremus Volodymyr Yevheniiovych PhD of Pedagogical Sciences, Lecturer at the Department of Ukrainian Studies, Vinnytsia National Medical University, Pirogov St., 56, Vinnytsia, 21018, tel.: (0432) 57-03-60, https://orcid.org/0000-0003-4370-1328

\section{DISTANCE LEARNING AS A CHALLENGE OF MODERN UNIVERSITY EDUCATION: PROBLEMS AND PROSPECTS}

Abstract. The article considers the concept of distance learning from the point of view of different scientists, outlines the requirements for the higher education system represented by the modern information society, explores the features of distance learning methods in higher education institutions. The modern tendencies in education which have arisen as a result of active use of distance learning methods in educational process are outlined. The assessment of the most important factors influencing the quality of distance learning in higher education is given. Requirements for the system of higher education, which provides a modern information society, have been formulated. In particular, it is noted that distance learning technologies are aimed at bridging the gap between the socio-economic situation of different groups and countries with different economic development. The list of conditions of use of various technologies of distance learning is established, the estimation of changes in modern education is given, in particular the 
necessity of accurate understanding of features of distance learning in comparison with traditional is emphasized. The question of the usefulness of distance learning is revealed. The article focuses on the features of educational trends that complicate the development of distance learning, and areas of reforming the modern educational process to introduce new approaches to distance learning. The system of challenges in the field of education related to distance learning is considered. In particular, it is noted that after studying the discipline the student must be clearly aware of what skills and competencies he has acquired. It is emphasized that effective distance interaction is one of the tools with which you can track all the weaknesses and strengths of the learning process, to identify gaps in it. The most important directions of distance learning university education are singled out, in particular Management and organizational support of distance education, logistical and financial support of distance learning, staffing of distance education needs, methodological support taking into account the specifics of distance learning, promotion of distance education in education and labor market. creation of a project to support distance learning students in different regions of Ukraine on the basis of free economic infrastructure.

Keywords: distance learning, form of education, educational programs, higher education, information technologies of e-learning.

Постановка проблеми. Відповідно до положень Концепції розвитку освіти України на 2015-2025 роки, актуальним завданням якісної освіти $€$ переорієнтація освітнього процесу на ефективну систему, спроможну формувати фахівців, конкурентоспроможних на європейському та світовому ринках праці відповідно до вимог прискореного економічного зростання та культурного розвитку національної та світової економіки [2].

Реалізацію цих спільних для всіх рівнів освіти завдань, у тому числі і для вищої освіти, слід здійснювати різними шляхами - через різноманітність підходів до роботи навчальних закладів, форм i методів навчання, впровадження сучасного менеджменту. Світовою тенденцією у системі вищої освіти $\epsilon$ широке використання дистанційного навчання. Проблема дистанційного навчання в українській освіті досить детально вивчена, але зі стрімкою зміною вимог до сучасних освітніх технологій виникають проблеми в її розвитку, які потребують нагального вирішення.

Аналіз останніх досліджень і публікацій. Тема дистанційного навчання в Україні вивчалася у працях Роберта I. [13], Малінко О. [10], Полат С. [12], Вишнівського В. [5 ], Н. Морзе [11] та інших науковців.

$\mathrm{У}$ роботах вітчизняних дослідників дистанційне навчання визначено як організацію навчального процесу, при якому викладач розробляє навчальний план на основі самостійного навчання студентів [12].

В останні роки дистанційна освіта зазнала значного розвитку, напрямки якого знайшли активне відображення у багатьох наукових роботах вітчизняних та зарубіжних науковців. Водночас поява нових на суттєве 
вдосконалення існуючих інформаційних технологій сьогодні ставить перед вищою школою освітні та наукові завдання, що потребують термінової оптимізації дистанційного навчання в університетах.

Мета статті - виявлення особливостей проблем та розгляд перспектив дистанційного навчання у вищих навчальних закладах.

Виклад основного матеріалу. Дистанційне навчання в сучасному розумінні було створено і отримало свій розвиток відносно недавно, а тому орієнтується на передовий методичний досвід, накопичений різними навчальними закладами світу, використання новітніх та найефективніших освітніх технологій, які відповідають запитам сучасної освіти та суспільства в цілому.

Звичайно, термін «дистанційне навчання» характеризується безліччю визначень, що вказує на різноманітність інтерпретаційних підходів, які передбачають інтерактивну взаємодію викладача та студентів у навчальному процесі, що забезпечує особистості резерв для самостійної роботи над освоєнням запропонованого матеріалу [9].

Вчений Роберт I. у своєму дослідженні «Теорія та методика інформатизації освіти» показує дистанційне навчання 3 точки зору процесу передавання знань, розвитку компетентності в контексті інтерактивного навчання, при якому відбувається взаємодія між студентом і викладачем за допомогою інтерактивних інформаційних ресурсів, що відображають всі елементи, характерні для навчального процесу (мета, цілі, організаційні форми, зміст, засоби навчання, методи) з використанням ІКТ з використанням різних видів інформації, комунікації та технологій [13].

Подібне тлумачення цього визначення запропонувала Полат $€$. «дистанційне навчання - це систематично організований процес навчання, побудований на взаємодії викладачів та студентів між собою на відстані, що відбиває всі властиві навчальному процесу елементи (організаційні форми, цілі, засоби навчання, зміст) своєрідними прийомами IКТ та Internetтехнологіями» [12, с. 23].

Вчений Хуторський А. трактує дистанційне навчання як: «...навчання, при якому суб'єкти знаходяться на відстані, реалізуючи навчальний процес за допомогою телекомунікацій».

Сучасне інформаційне суспільство висуває вимоги до системи університетської освіти, які можна сформулювати так:

- здатність самостійно знаходити, накопичувати та переосмислювати наукові знання;

- вміння студентів самостійно орієнтуватися в сучасному інформаційному суспільстві.

Для вирішення проблеми якості освітніх послуг, які отримують студенти при дистанційному навчанні, викладачам необхідно розробити та впровадити інформаційні технології, що стимулюють розвиток дистанційного навчання. Дистанційне навчання в університеті надає студентам можливість мати 
Журнал«Герспективитаінновації науки

(Серія«Гедагогіка», Серія«ГЕихологія», Серія«Медицина»

№1(6) 2022

цілодобовий доступ до навчальних матеріалів, постійну підтримку та консультації викладачів і методистів, відеолекції, віртуальні тренажери та інші технологічні рішення для забезпечення ефективного навчального процесу.

Розвиток дистанційного навчання потребує значних капіталовкладень, що дає можливість придбати необхідне обладнання та підготувати не лише педагогічний, а й адміністративно-технічний персонал. Головне завдання тих, хто сьогодні керує процесом впровадження та використання сучасних освітніх технологій - зробити цей процес максимально ефективним та мінімізувати помилки, для чого необхідно активно обмінюватися досвідом між різними закладами вищої освіти [3].

Сьогодні десятки українських ЗВО пропонують дистанційне навчання, яке має ряд особливостей та переваг перед традиційними (денною та заочною) формами:

- безперервність навчання - можливість навчання в будь-який час за індивідуальним графіком;

- доступність освітніх ресурсів - їх відкритість для масової участі всіх груп населення в освітньому процесі;

- економічність - забезпечення високоякісної освіти 3 мінімальними фінансовими та енергетичними витратами;

- індивідуалізація та диференціація навчання - створення та адаптація дистанційних курсів $з$ урахуванням вікових та фізіологічних особливостей користувача;

- інноваційність - використання нових засобів інформації та комунікації при створенні якісного освітнього середовища для навчання та розвитку навичок не лише у професійних сферах, а й для набуття комп'ютерної грамотності;

- мобільність - можливість паралельно та без відриву від професійної діяльності навчатися в іншій сфері.

Під час карантину гнучкість та різномаїття інструментарію дистанційного навчання дозволяє використовувати його технології для очної форми навчання (екзаменаційні завдання, моніторинг рівня навичок та умінь), у поєднанні із заочною формою (онлайн-консультації, конференц-дзвінки) та як i окрема форма навчання (веб-курси, тренінги). Завдяки новітнім інструментам усі необхідні освітні ресурси (підручники, посібники, навчальні матеріали, навчальне програмне забезпечення тощо) зберігаються в єдиному хмарному сховищі [6].

Однак $є$ деякі недоліки використання дистанційного навчання, які необхідно усунути:

- перерви в доступі до віддалених ресурсів, які можуть призвести до втрати або пошкодження даних;

- некомпетентність деяких викладачів щодо організації дистанційного навчання з використанням нових інформаційно-комунікаційних технологій;

- складність контролю при самостійному виконанні завдань; 
- комплексність мотивації та контроль своєчасності виконання завдань шляхом надання більшості навчального матеріалу для самостійного опрацювання;

- складність організації спільної діяльності для спілкування та обміну досвідом.

При цьому дистанційне навчання має враховувати певні комунікаційні обмеження:

- деяка ізоляція студента у віртуальній академічній групі;

- обмеження, що перешкоджають розвитку групового спілкування, групової єдності;

- технічні засоби групової комунікаційної діяльності вчителя та учня створюють штучний i дефективний, у традиційному розумінні, комунікативний простір;

- нездатність чітко висловлювати свої думки, особливо в чатах та текстових повідомленнях;

- труднощі у зміні власної позиції під час навчання.

Широке впровадження та розвиток дистанційного навчання у $3 \mathrm{BO}$ України потребує вирішення низки завдань за такими напрямками:

- управлінська та організаційна підтримка;

- матеріально-технічне та фінансове забезпечення;

- кадрове забезпечення потреб дистанційної освіти;

- методичне забезпечення 3 урахуванням специфіки дистанційного навчання;

- сприяння просування дистанційного навчання в освіті та на ринку праці;

- створення проекту підтримки дистанційних форм навчання студентів у різних регіонах України на базі ЗВО;

- турбота про здоров'я всіх учасників дистанційного навчання, що є найважливішою частиною організації ефективного дистанційного навчання.

Своєчасне використання технологій дистанційного навчання гарантує для закладів вищої освіти:

- значне збільшення суб'єктів навчального процесу (організація навчання для широкої аудиторії - одночасна участь великої кількості студентів);

- значне зниження витрат на організацію навчального процесу (відсутність витрат на оренду, економія на рахунках за електроенергію тощо);

- значне підвищення якості освіти засобами електронних бібліотек, використання сучасних IКT, збільшення обсягу самостійної роботи студентів, викладачів тощо;

- Організація єдиного (універсального) інформаційного освітнього середовища для вищих навчальних закладів.

Сучасні комп'ютерні телекомунікації здатні забезпечити знання та доступ до широкого спектру освітньої інформації в такому ж обсязі, а іноді й набагато більшому, ніж традиційні засоби навчання. Якість і структура навчальних курсів, а також якість викладання в дистанційному навчанні значно кращі, ніж 
Водночас сучасні світові тенденції свідчать про такі труднощі та ризики для України, пов’язані з проблемами дистанційного навчання (табл. 1):

\section{Тенденції в освітній галузі, що ускладнюють розвиток дистанційної освіти}

\begin{tabular}{|l|l|}
\hline $\begin{array}{c}\text { Tенденції в } \\
\text { освітній галузі }\end{array}$ & \multicolumn{1}{|c|}{ Характеристика ризику, спричиненого тенденцією в освітній } \\
галузі
\end{tabular}

Навчання протягом усього життя передбачає збільшення

Утвердження в освітній політиці розвинених країн концепції «освіта протягом життя»

Перехід освітніх систем розвинених країн до широкого використання інформаційних технологій.

\section{Стрімке} зростання ролі інформаційних технологій інвестицій у людей та знання; набуття базових навичок, включаючи цифрові навички; поширення інноваційних та гнучких форм навчання. Мета навчального процесу - надати людям різного віку рівний та відкритий доступ до якісної освіти. Рада Європи виступає за навчання протягом усього життя як ключового компонента європейської соціальної моделі. Така підготовка не обмежується лише освітою - вона також $\epsilon$ вирішальним фактором зайнятості та соціального забезпечення, економічного зростання та конкурентоспроможності.

Це призводить до посилення конкуренції на міжнародному ринку освіти. Стрімкий розвиток проектів дистанційного навчання в найближчі кілька років може витіснити значну частину традиційних навчальних закладів багатьох країн. Принцип максимальної доступності освітніх ресурсів зараз навіть став стандартом провідних університетів світу. Аналітики прогнозують, що найближчим часом всесвітньо відомі університети зможуть навчати десятки мільйонів студентів 3 усього світу замість сотень тисяч студентів.

Інформаційні технології знаходяться на першому плані в усіх сферах життя як окремої людини, так і суспільства в цілому. Широке використання інформаційних технологій у дистанційному навчанні дозволить, окрім оволодіння певним набором знань і компетенцій, закладених у навчальні програми, досягти певного рівня знань i навичок роботи з інформаційними технологіями, необхідного сучасній людині. Таким чином, інформаційні технології - обов'язкова умова успіху та якості життя. 


\begin{tabular}{|l|l|}
\hline \multirow{2}{*}{ Демографічний } & \multicolumn{1}{|c|}{ Падіння народжуваності та старіння населення вимагають } \\
синнокення умов для навчання дорослих і людей похилого віку, які в \\
переважній більшості встигають над умовами життя (сім'я, робота, \\
місце проживання тощо) і визначають актуальність різних форм. \\
дистанційного навчання.
\end{tabular}

Джерело: сформовано автором на на основі [6].

Варто відзначити деякі негативні моменти, які можуть виникнути при впровадженні дистанційного навчання в навчальний процес:

- надто слабка координаційна функція Міносвіти (неузгодженість у нормативно-правовому забезпеченні, у стандартизації, в економічних та фінансових питаннях, в оцінюванні якості освіти).

- Конкурс університетів за студентів як основне джерело фінансування призвів до автономії багатьох університетів та обмеження їх розвитку, що також пов'язано з тим, що питання авторського права не вирішуються.

- людський фактор відіграє важливу роль у процесі навчання, оскільки вчитель може передати ряд навичок у безпосередньому контакті зі студентом і повністю або частково зникає під час дистанційного навчання.

- існуючі методи навчання погано поєднуються 3 новими технологіями, а більшість навчальних матеріалів не придатні для дистанційного навчання.

- дистанційне навчання неможливе в деяких предметних областях, оскільки деякі дисципліни вимагають складних лабораторних практикумів, які проводяться під керівництвом викладача.

- багато викладачів не володіють інформаційними технологіями. Через це виникають труднощі зі створенням навчального матеріалу, придатного для дистанційного навчання.

- опір педагогічного колективу впровадженню сучасних технологій.

- витрати на навчання викладачів сучасним інформаційним технологіям, а також фінансові витрати ВНЗ на придбання необхідного технічного обладнання.

- необхідність стандартизації вимог до наданих навчальних матеріалів дистанційного навчання.

- техні технічно слабкі канали зв'язку, високі витрати, пов'язані з його утриманням.

- створення інформаційно-освітнього середовища, особливо щодо наповнення бази електронними підручниками та навчальними матеріалами.

- підвищення пропускної спроможності телекомунікаційного каналу, розвиток корпоративної мережі університетів та філій до рівня, що забезпечує організацію навчального процесу за всіма видами освітньої діяльності та освітніми комунікаційними технологіями.

Вирішення вищезазначених проблем можливе шляхом впровадження дистанційного навчання у сфері освіти на основі нових інформаційних технологій та сучасного підходу до планування та функціонування навчального процесу. 
Журнал«Герспективита інновації нукиљ

(Серія «Гедагогіка», Серія«Гцихологія», Серія«Медицина»

№(6) 2022

Основні напрямки цього підходу:

- комп'ютеризація наявного навчального та наукового лабораторного обладнання на основі сучасних засобів і технологій;

- розробка нового покоління засобів навчання 3 використанням комп'ютерних моделей, анімації та фізичного моделювання об'єктів, процесів і явищ;

- методики навчання повинні підтримувати комп'ютерні форми навчання, контролю знань, отримання індивідуального завдання, моделювання дослідницьких процесів, проведення експерименту, аналізу та обробки результатів експерименту, у тому числі в режимі віддаленого доступу;

- створення системи віддаленого доступу ЗВО до ресурсів інших університетів i через них до навчально-наукових лабораторій i наукових центрів на всій території країни;

- збільшення пропускної здатності комунікаційних каналів до показників, необхідних для забезпечення потреб процесу дистанційного навчання;

- розробка електронних підручників та навчально-методичних матеріалів та створення бази дистанційного навчання;

- придбання та впровадження мережевих ресурсів;

- консолідація зусиль організаторів дистанційного процесу навчання та розробників програмного забезпечення;

- дослідження, придбання та впровадження існуючих електронних підручників та навчально-методичних матеріалів;

- створення єдиної корпоративної системи дистанційного навчання та спільних ресурсів;

- організація підготовки та підвищення кваліфікації викладачів і технічних працівників у галузі методики та інформаційних технологій дистанційного навчання;

- створення електронної бібліотеки, включення іiі до корпоративної мережі бібліотек області,

- надання доступу до відкритих бібліотек;

- створення центру дистанційного навчання на базі вільних економічних відносин України, вступ до Міжнародної асоціації відкритих електронних бібліотек, інших профільних організацій;

- створення єдиної міжвузівської системи контролю дистанційного навчання, що займається розробкою єдиних норм і стандартів, методичним забезпеченням удосконалення навчального процесу та селекцією.

Для їх успішного вирішення об’єктивно необхідно реалізувати такі першочергові заходи та напрями: розвиток та впровадження всеукраїнського дистанційного навчання; усунення суперечностей в освітньому законодавстві в Україні та адаптація до об'єктивних потреб і тенденцій дистанційного навчання; розвиток науки, яка дає змогу впроваджувати інновації як у формах дистанційного навчання, так і в рівнях освіти, програм і навчальних планів; наукове забезпечення ринку навчальної літератури, комп'ютерних та 
мультимедійних баз даних, виключення можливості монополізму; створення різних методів дистанційного навчання для людей різних здібностей, віку та потреб; забезпечення переходу на інтерактивні методи та практичну спрямованість дистанційного навчання; створення системи підтримки проектів, інновацій у технологіях дистанційного навчання, їх листування та інших форм; надання вступної кваліфікації до ВНЗ, отримання атестатів та дипломів у різних навчальних закладах.

Дистанційна освіта надає широке поле для досліджень, що заохочує розробників і педагогів до розвитку творчих ініціатив, які переходять від об'єкта дослідження до об'єкта прогнозування, конструювання та проектування.

Відсутність роботи відповідно до вище зазначених викликів створить загрози національним інтересам України, зокрема: погіршення якості людського капіталу; зниження конкурентоспроможності вітчизняної освіти; затримку економічного розвитку, а отже і уповільнення євроінтеграційних процесів.

Поширення університетського дистанційного навчання $є$ важливим механізмом інформатизації та інтелектуалізації суспільства, формування різноманітних особистостей, подолання нерівності в системі освіти. Дистанційне навчання долає територіальний фактор нерівності у доступі до якісної вищої освіти, залежність від місця проживання тощо. Основне джерело інформації, запроваджене в процесі дистанційного навчання за найновішими технологіями, $є$ рушієм інноваційного розвитку освіти та суспільства в цілому.

Широке впровадження та розвиток дистанційного навчання в Україні потребує вирішення низки завдань за такими напрямками: управлінське та організаційне забезпечення; матеріально-технічне та фінансове забезпечення; задоволення вимог до кадрового забезпечення дистанційного навчання; методичне забезпечення 3 урахуванням специфіки дистанційного навчання; просування дистанційного навчання в освіті та на ринку праці (рис. 1).

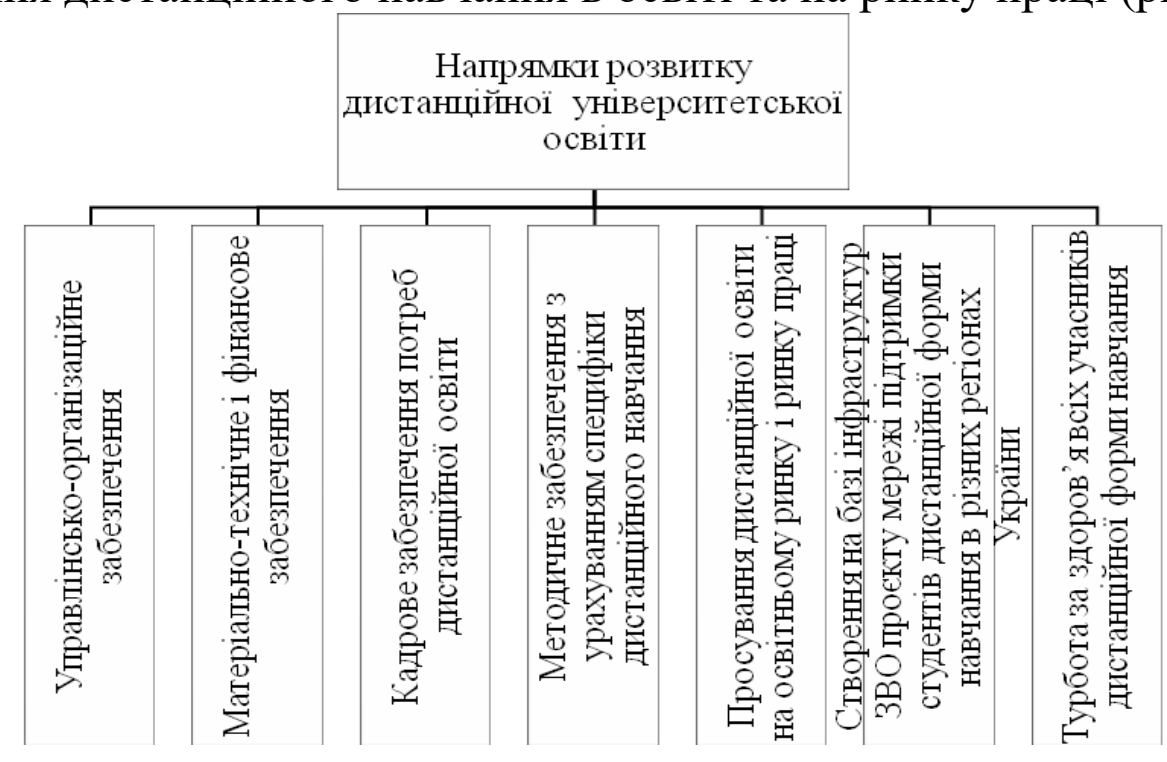

Puс. 1 Основні напрямки розвитку дистанційної університетської освіти Джерело: сформовано автором на на основі [9]. 
Журнал«Герспективитаіновації наукиљ

(Серія«Гедагогіка», Серія«ГЕихологія», Серія«Медицина»

№1(6) 2022

Отже, вдосконалення та поширення дистанційних технологій вимагає вирішення двох основних типів проблем. Як бачимо, одні з них у правовому полі, інші - у сфері фінансування розробки та впровадження інноваційних технологій.

Більшість українських викладачів не мають значного досвіду використання онлайн-засобів навчання, тому університети повинні навчати процесу формування навичок використання цих інструментів, створення чи передачі онлайн-курсів та організації навчання загалом - шляхом надання інструкцій, створення каналів на YouTube, Telegram, груп у Facebook, розробляти інструкції зі створення навчальних програм для змішаного навчання тощо.

Варто зазначити, що останнім часом важливою проблемою стало збільшення навантаження на навчання, особливо звертає на себе увагу потреба у додаткових витратах часу, необхідних для оволодіння навичками використання цифрових технологій при формуванні, створенні чи передачі навчальних курсів для дистанційного навчання, їх регулярне оновлення, доповнення та спілкування зі студентами. Слід зазначити, що час, необхідний для спілкування зі студентами, збільшився, оскільки письмове пояснення завдання (або додавання опису до онлайн-курсу) займає більше часу, ніж при очном навчанні, а також будь-які додаткові індивідуальні запитання студентів, а листування з ними також збільшує робочий час викладачів. Іншою причиною позанормованого робочого часу стала необхідність розробки уроків у новому форматі та пошуку додаткових матеріалів. У той же час у деяких університетах зберігався змішаний формат навчання, тому вчителям доводилося працювати в аудиторії, крім роботи в Інтернеті.

Дистанційне навчання ставить перед викладачем ЗВО нові завдання. Викладачі повинні бути готові обирати якісні технології для реалізації дистанційної взаємодії. Студент, у свою чергу, повинен навчитися нести відповідальність за зміст інформації, яку він надав, мати навички спілкування та співпраці, критично мислити та вміло керувати конфліктними ситуаціями. Після вивчення будь-якої дисципліни студент повинен мати чітке уявлення про те, які навички та компетенції він набув, а ефективна дистанційна взаємодія є одним із інструментів, який допоможе відстежити всі його слабкі та сильні сторони, виявити та оцінити прогалини в знаннях.

Тому метою впровадження дистанційного навчання у ЗВО є організація якісного навчального процесу «на дистанції» 3 використанням новітніх інформаційно-комунікаційних засобів та відкритого доступу до освітніх ресурсів. Така форма навчання дозволяє швидко адаптуватися до вимог інформаційного суспільства та підготувати майбутніх спеціалістів. У поєднанні з традиційними формами (змішана система навчання), дистанційне навчання у закладах вищої освіти може запропонувати широкий спектр освітніх можливостей як для абітурієнтів, так і для студентів з метою набуття необхідних навичок та вмінь для подальшої професійної діяльності, а також 
для виклалачів, щоб удосконалити їх знання та навички.

Висновки. Отже, у сучасних глобальних реаліях традиційна національна система вищої освіти лише частково відповідає запитам студентської аудиторії та інформаційного суспільства до майбутніх фахівців, i лише завдяки використанню дистанційних, а саме інтернет- та мобільних технологій викладачі та студенти можуть працювати у партнерстві як за умов викладання в аудиторії, так і за межами університету.

\section{Лimepamypa:}

1. Закон України Про вищу освіту: [Електронний ресурс]. - Режим доступу: http://zakon4.rada.gov.ua/laws/show/1556-18/print1389899592029395

2. Концепція розвитку освіти в Україні на період 2015-2025 років [Електронний ресурс]. Режим доступу: URL: http://osvita.ua/doc/files/news/435/43501/project_30102014.doc (2014).

3. Рекомендації МОН України щодо впровадження змішаного навчання у закладах фахової передвищої та вищої освіти [Електронний ресурс]. - Режим доступу: https://mon.gov.ua/ua/osvita/vishaosvita/rekomendacij-shodo-vprovadzhennya-zmishanogonavchannya-u-zakladahfahovoyi-peredvishoyi-ta-vishoyi-osviti

4. Наказ Міністерства освіти і науки України «Про затвердження положення про дистанційне навчання». [Електронний ресурс]. - Режим доступу: http://zakon4.rada.gov.ua/ laws/show/z0703-13/print1389899592029395

5. Вишнівський В. Організація дистанційного навчання. Створення електронних навчальних курсів та електронних тестів: навч. посіб. / В. Вишнівський. - К.: ДУТ, 2014. -140 с.

6. Власенко Л. Переваги та недоліки дистанційного навчання Професійна підготовка педагога : історичний досвід і виклики сучасності : збірник наукових праць. / Дрогобич: Редакційно-видавничий відділ Дрогобицького державного педагогічно університету ім. I. Франка, 2013. - с. 224-228.

7. Кухаренко В., Бондаренко В. Екстрене дистанційне навчання в Україні: Монографія. - Харків: Вид-во КП «Міська друкарня», 2020. - 409 с.

8. Кучеренко Н. Дистанційне навчання як виклик сучасної університетської освіти: філософсько-правовий вимір. [Електронний ресурс]. - Режим доступу: https://science.lpnu.ua/sites/default/files/journal-paper/2019/sep/18362/8.pdf

9. Ляшенко I. Перспективи розвитку дистанційного навчання у вищій школі [Електронний ресурс] / I. Ляшенко // Народна освіта. - 2015. №1(25), Режим доступу: https://www.narodnaosvita.kiev.ua/?page_id=2682

10. Малінко О. Дистанційна освіта: організаційна структура, психолого-педагогічні основи, фінансування і управління. / О. Малінко // Директор школи, ліцею, гімназії. 2002. - № 6. - c. 38-45.

11. Морзе Н., Глазунова О. Критерії якості електронних навчальних курсів, розроблених на базі платформ дистанційного навчання. / Н. Морзе, О. Глазунова // Інформаційні технології в освіті. - 2009. - № 4. - с. 63-75.

12.Полат Е. Теория и практика дистанционного обучения: - М.: Академия, 2004. - 416 с.

13. Роберт И. Теория и методика информатизации образования (психологопедагогический и технологическийаспекты). 2-е издание, дополненно: монография. - М.: ИИО РАО. 2008. - 274 с. 


\section{References:}

1. Zakon Ukraïni «Pro vishhu osvitu» [The Law of Ukraine «On Higher Education»] (n.d.). zakon.rada.gov.ua. Retrieved from http://zakon4.rada.gov.ua/laws/show/155618/print1389899592029395 [in Ukrainian].

2. Koncepcija rozvitku osviti v Ukraïni na period 2015-2025 rokiv [The concept of education development in Ukraine for the period 2015-2025]. (2014). Retrieved from http://osvita.ua/doc/files/news/435/43501/project_30102014.doc [in Ukrainian].

3. Rekomendaciï MON Ukraïni shhodo vprovadzhennja zmishanogo navchannja u zakladah fahovoï peredvishhoï ta vishhoï osviti [Recommendations of the Ministry of Education and Science of Ukraine on the implementation of blended learning in institutions of professional higher and higher education] Retrieved from https://mon.gov.ua/ua/osvita/vishaosvita/rekomendacij-shodovprovadzhennya-zmishanogo-navchannya-u-zakladahfahovoyi-peredvishoyi-ta-vishoyi-osviti [in Ukrainian].

4. Nakaz Ministerstva osviti i nauki Ukraïni «Pro zatverdzhennja polozhennja pro distancijne navchannja» [Order of the Ministry of Education and Science of Ukraine «On approval of the regulations on distance learning]. Retrieved from http://zakon4.rada.gov.ua/laws/show/ z0703-13/print1389899592029395 [in Ukrainian].

5. Vishnivs'kij V. (2014) Organizacija distancijnogo navchannja. Stvorennja elektronnih navchal'nih kursiv ta elektronnih testiv testiv [Organization of distance learning. Creation of electronic training courses and electronic tests]: navch. Kiïv: DUT [in Ukrainian].

6. Vlasenko L. (2013) Perevagi ta nedoliki distancijnogo navchannja [Advantages and disadvantages of distance learning] Profesijna pidgotovka pedagoga : istorichnij dosvid i vikliki suchasnosti : zbirnik naukovih prac'. Drogobich: Redakcijno-vidavnichij viddil Drogobic'kogo derzhavnogo pedagogichno universitetu im. I. Franka [in Ukrainian].

7. Kuharenko V., Bondarenko V. (2020) Ekstrene distancijne navchannja v Ukraïni [Emergency distance learning in Ukraine]: Monografija.Harkiv: Vid-vo KP «Mis'ka drukarnja» [in Ukrainian].

8. Kucherenko N. (2019) Distancijne navchannja jak viklik suchasnoï universitets'koï osviti: filosofs'ko-pravovij vimir. [Distance learning as a challenge of modern university education: philosophical and legal dimension.] Retrieved from https://science.lpnu.ua/sites/ default/files/journal-paper/2019/sep/18362/8.pdf [in Ukrainian].

9. Ljashenko I. (2015) Perspektivi rozvitku distancijnogo navchannja u vishhij shkoli. [Prospects for the development of distance learning in higher education]Narodna osvita. Vipusk №1(25), r. Retrieved from https://www.narodnaosvita.kiev.ua/?page_id=2682 [in Ukrainian].

10. Malinko O. (2002) Distancijna osvita: organizacijna struktura, psihologo-pedagogichni osnovi, finansuvannja i upravlinnja. Direktor shkoli, liceju, gimnaziii. № 6. c. 38-45.

11. Morze N., Glazunova O. (2009) Kriterii jakosti elektronnih navchal'nih kursiv, rozroblenih na bazi platform distancijnogo navchannja [Quality criteria for e-learning courses developed on the basis of distance learning platforms.]. Informacijni tehnologiï v osviti. Herson. № 4. [in Ukrainian].

12. Polat E. (2004) Teorija i praktika distancionnogo obuchenija [Theory and practice of distance learning]: M.: Akademija. [in Ukrainian].

13. Robert I. (2008) Teorija i metodika informatizacii obrazovanija (psihologopedagogicheskij i tehnologicheskijaspekty) [Theory and methods of informatization of education (psychological, pedagogical and technological aspects]. 2-e izdanie, dopolnenno: monografija. M.: IIO RAO. [in Ukrainian]. 